\title{
Seasonal and diurnal variability in carbon respiration, calcification and excretion rates of the abalone Haliotis tuberculata $L$.
}

\author{
Chapperon Coraline ${ }^{2,3}$, Clavier Jacques ${ }^{3}$, Dugué Clément ${ }^{3}$, Amice Erwan ${ }^{1}$, Le Goff Marion ${ }^{3}$,
} Roussel Sabine ${ }^{3, *}$

${ }^{1}$ Laboratoire des Sciences de I'Environnement Marin (LEMAR), UMR 6539 UBO, CNRS, IRD, IFREMER, Institut Universitaire Europe'en de la Mer (IUEM), rue Dumont d'Urville, 29280 Plouzane', France

${ }^{2}$ School of Biological Sciences, Flinders University, Sturt Rd, Bedford Park, Adelaide, 5042, South Australia

* Corresponding author : Sabine Roussel, email address : sabine.roussel@univ-brest.fr

\begin{abstract}
:
Abalone (Haliotis spp.) are commercially important marine shellfish species worldwide. Knowledge about the physiology of abalone that impacts life-history traits is important for a better understanding of the biology of the species and the impact of stressful husbandry procedures at different seasons. The present study quantified the seasonal and diurnal variations in four physiological parameters of the European species Haliotis tuberculata, i.e. carbon aerial and aquatic respiration, calcification and excretion rates, and the effect of prolonged aerial exposure upon abalone aerial respiration. We also investigated the effect of individual size upon these physiological parameters. Aquatic respiration and calcification rates showed an allometric relationship with biomass. All parameters showed lower rates in cool season and higher rates in warmer season. Temperature was assumed to be the primary driver of the reported seasonal variability in physiological parameters, although reproductive needs and nutrition may also contribute to the observed patterns. Importantly, abalone did not stop calcifying in winter, and calcified more at night than during the day. Abalone did not respire more underwater at night-time than at daytime, however they excreted more overnight. The low air:aquatic ratio $(0.2)$ is likely to be an energy-saving strategy for emerged $H$. tuberculata individuals. This study highlights the temporal heterogeneity in physiological rates of $H$. tuberculata, which constitutes a species
\end{abstract}

Keywords : ormer, metabolism, carbon fluxes, physiology 


\section{INTRODUCTION}

37 Abalone (Haliotis species) are commercially important marine gastropod species worldwide.

Whilst abalone fisheries declined from 19720 to 7486 metric tonnes between 1970 and 2013, farming production exploded from 50 to 103464 metric tonnes over the same period (Cook, 2014). The decrease in abalone fisheries has been triggered by overexploitation, illegal catches and disease that lessened wild abalone stocks (Cook, 2014). Haliotis tuberculata L. is the only species present in Europe (van Wormhoudt et al., 2011). This species is relatively abundant on the Channel Islands and the Atlantic coast of France (Clavier \& Richard, 1982;

Gaty \& Wilson, 1986). In the wild, H. tuberculata is sedentary (Forster, 1967) and found at the subtidal and low intertidal levels in shallow rocky habitats (Hayashi, 1983). Their biology and ecology such as their reproductive cycle (Hayashi, 1980a), population structure and growth (Hayashi, 1980b; Clavier \& Richard, 1986; Roussel et al., 2011) have been well studied. Respiration rates of $H$. tuberculata from hatcheries (oxygen consumption rates in $\mathrm{mg}$ or $\mathrm{ml} \mathrm{O}_{2} \mathrm{~h}^{-1}$ ) have previously been investigated in regards to factors such as e.g. body size (10-50mm, Gaty \& Wilson, 1986; 10-90g, Basuyaux et al., 2001) and simulated temperature $\left(8,16\right.$ and $24^{\circ} \mathrm{C}$ in Gaty \& Wilson, 1986 , and $12,15,18,21,28^{\circ} \mathrm{C}$ in Basuyaux et al., 2001). Nonetheless, the natural variations (day-night and season cycles) in the metabolism of abalone from the natural habitat and the effect of body size upon respiratory rates in mature individuals (i.e. size over 50mm, Hayashi, 1980a), are still not well understood and represent important biological information for the recently developed industry in Europe (Roussel et al., 2013; Cook, 2014; Lachambre et al., 2017). Indeed, many abalone farms rely on coastal seawater and hence factors such as seawater temperature or dissolved oxygen which vary according to season, day-night and tidal cycles are likely to impact abalone physiology (Morash \& Alter, 2015). A better understanding of the natural temporal variations in 
can thus contribute to improving fisheries management and aquaculture development (Young et al., 2006; Cooke et al., 2014; Ragg \& Watts, 2015; Gao et al., 2016).

Several factors can modify abalone metabolism such as light quality (H. discus discus, Gao et al., 2016), infection (H. rufescens and H. discus hannai, González et al., 2012; H. diversicolor, Lu et al., 2017), farm stressors such as density, high temperature and ammonia concentration (see review from Morash \& Alter, 2015). To increase our understanding of the effects of environmental and farm stressors upon abalone physiology, it is first necessary to better comprehend the natural temporal variability in abalone metabolism and biology. In particular, seasons have a strong effect on chemical constituents in the muscle and viscera $(H$. diversicolor, Chiou et al., 2001; H. laevigata and Haliotis rubra, Su et al., 2006; farmed Jade Tiger hybrid abalone, Mateos et al., 2010), metabolic activity of digestive-gland cells ( $H$. kamtschatkana, Carefoot et al., 1998), textural proprieties (Hariltis discus, Hatae et al., 1995) and even immunity parameters of abalone (H. tuberculata, Travers et al., 2008). These variations are partly related to reproductive cycle and energy transfer. However, to our knowledge, the season effect upon abalone (including $H$. tuberculata) metabolism has been poorly investigated to date.

Abalone metabolism might also vary according to diurnal rhythm. Indeed, abalone are nocturnal gastropods. They are active, move and feed mainly over-night in laboratory conditions, and in their natural habitat (H. discus hannai, Momma \& Sato, 1970; H. laevigata, H. roei, H. ruber, H. cyclobates, H. scalaris, Shepherd, 1973). One can thus expect that abalone (and thus H. tuberculata) metabolism is greater at nighttime in order to fulfill the metabolic needs related to individuals' nocturnal behavior.

Finally, others stressors related to commercial practices such as high water ammonia concentration, high density, and air exposure (see review from Morash \& Alter, 2015) are likely to impact the physiological rates of abalone. Nitrogenous waste can be toxic and limit 
86

87

88

production in aquaculture (Ahmed et al., 2008) and thus likely impact the physiology of abalone. Both fished abalone (H. iris, Wells \& Baldwin, 1995; Ragg \& Watts, 2015, $H$. australis, Wells \& Baldwin, 1995) and farmed abalone (H. tuberculata, Lachambre et al., 2017) can be exposed to air during handling procedures. Abalone have been demonstrated to remain metabolically active during air exposure at a much lower rate than during immersion (H. iris, Baldwin et al., 1992). H. tuberculata can be found at low shore levels on rocky shores during extreme spring tides or even at higher levels in large rockpools (Crofts, 1929). It is thus expected that $H$. tuberculata is physiologically adapted to aerial exposure. Nevertheless, periods of exposure to air longer than those experienced in natural conditions, and at different temperature, can occur especially during live shipments. A greater understanding of abalone (and hence $H$. tuberculata) metabolic capacities under aerial conditions is therefore important to improve the transport and handling of live animals.

This study proposed to study the natural temporal variations in physiological parameters of $H$. tuberculata. We quantified the seasonal, diurnal variations as well as the effect of individual size on four physiological parameters i.e. carbon aerial and aquatic respiration, calcification and excretion rates which are key parameters to understand abalone physiology (Morash \& Alter, 2015). In addition, aerial respiration was studied during a 6-h exposure and in different temperature conditions to study the effect of temperature on the aerial metabolic rate. 


\section{MATERIALS AND METHODS}

\section{Sampling}

107 Abalone were collected by divers equipped with diving tanks in the Bay of Brest, in Brittany,

108 NW of France. The sampling site was situated on the east part of the "Ile des Morts" in the

109 Bay of Roscanvel located on the SW part of the Bay of Brest $\left(48^{\circ} 18,225^{\prime} \mathrm{N}, 4^{\circ} 32,134^{\prime} \mathrm{W}\right.$,

110 France). Abalone were found under rocks at a depth between $3 \mathrm{~m}$ and $10 \mathrm{~m}$ depending on the

111 tide. They were carefully removed by hand, placed into a net until the end of the diving

112 session and subsequently placed within a closed transportable tank containing seawater.

\section{Laboratory conditions}

115 In the laboratory, abalone were placed into a flow through system and kept unhandled for at

116 least 24 hours before starting any measurements to minimize handling stress. Filtered

117 seawater was provided from the Bay of Brest by the nearby pumping station of the Institut

118 français pour l'exploitation de la mer (Ifremer) at Sainte-Anne du Portzic. Seawater

119 temperature was thus at the same temperature as in situ. A mix of algae from their natural 120 habitat was added for food.

\section{Methodology}

\section{SEASON COMPARISON IN ALL PHYSIOLOGICAL PARAMETERS}

124 Aquatic and aerial respiration rate, calcification rate and ammonium excretion rate were 125 calculated in adult abalone collected in the four seasons (Figure $1, n=16$ in summer, $n=15$

126 in autumn, $\mathrm{n}=17$ in winter and in spring). These sampling periods were especially chosen to

127 test the effect of seawater temperature upon the measured parameters. For instance, seawater

128 temperature recorded in $2014-2015$ was on average $17.1 \pm 0.4{ }^{\circ} \mathrm{C}(\bar{x} \pm S D$, mean \pm standard

129 deviation) in summer $\left(18.3^{\circ} \mathrm{C}\right.$ in September experimental day), $15.1 \pm 2.2{ }^{\circ} \mathrm{C}$ in autumn 
$130\left(14.6^{\circ} \mathrm{C}\right.$ in November experimental day), $10.5 \pm 0.9{ }^{\circ} \mathrm{C}$ in winter $\left(11^{\circ} \mathrm{C}\right.$ in January 131 experimental day) and $13.2 \pm 1.8^{\circ} \mathrm{C}$ in spring $\left(14.1^{\circ} \mathrm{C}\right.$ in May experimental day) (SOMLIT:

132 Service d'Observation en Milieu Littoral, INSU-CNRS, St Anne du Portzic; Figure 1).

133 Abalone ranging from $70 \mathrm{~mm}$ to $80 \mathrm{~mm}$ in length were sexually mature i.e. size over 50

$134 \mathrm{~mm}$ (Hayashi, 1980a). This size range, corresponding to adult individuals, is the most

135 abundant in the sampling area and was selected to facilitate sampling. Aquatic incubations

136 were performed around midday in each season. Aerial respiration rates were measured upon

137 emersion as soon as individuals were removed from their aquatic incubation bottle. As

138 animals were free to feed prior to experiments, measured metabolic rate may include

139 postprandial metabolic demand.

140

DIURNAL COMPARISON IN AQUATIC PHYSIOLOGICAL PARAMETERS

142 In order to compare metabolic rates which can vary through time at a diurnal scale (Lorrain et 143 al., 2015), aquatic incubations were repeated overnight in autumn (November 2014) on the

144 same individuals to compare aquatic respiration, calcification and excretion rates during day 145 and night periods.

INDIVIDUAL SIZE EFFECT UPON AQUATIC PHYSIOLOGICAL PARAMETERS

148 Calcification, aquatic respiration and ammonium excretion rates were calculated in abalone (n $149=45$ ) from a wide range of size (length: 35 to $106 \mathrm{~mm}$ ) in September 2014. Smaller 150 individuals $(<50 \mathrm{~mm}, \mathrm{n}=15$ abalone for a total of 107 abalone tested) were provided by the 151 France Haliotis abalone farm (4836'46N; 4³3'30W, Plouguerneau, France). These abalone 152 were the third generation bred in the farm and resulted from systematic mating between wild 153 and farmed broodstock (either males or females were wild broodstock) for each generation. 
156 Abalone $(n=8)$ were gently detached from the laboratory tank and emersed for 6 hours.

157 Individual aerial respiration rates were measured each hour in spring (May 2015) at $14^{\circ} \mathrm{C}$.

158 Incubations were also conducted at $18^{\circ} \mathrm{C}$ and $10^{\circ} \mathrm{C}$ on successive days. These air temperatures

159 were chosen as they are representative of the temperature that can be experienced by abalone

160 during either ambient temperature or cooled temperature transport. The spring season was

161 chosen because it corresponds to usual fishing period for H. tuberculata (fishing is forbidden

162 in summer in Europe and practically difficult for the fisherman in winter due to poor weather

163 conditions).

164

165 Physiological measurements

166 Aquatic incubations of 1.5 to 2 hours (dark conditions) were conducted to calculate abalone

167 aquatic respiration (dissolved inorganic carbon, DIC), calcification/decalcification $\left(\mathrm{CaCO}_{3}\right)$

168 and ammonium excretion $\left(\mathrm{NH}_{4}^{+}\right.$fluxes). Individuals were gently detached and placed into 2-L

169 watertight plastic bottles filled with natural filtered seawater ( 1 individual/bottle) immersed

170 into a $580 \mathrm{~L}$ tank filled with running seawater to maintain a constant temperature during

171 incubations. Bottles were gently rotated once in the middle of incubations to ensure

172 homogenization.

\section{AQUATIC RESPIRATION RATE}

175 Aquatic respiration within each bottle $\left(R, \mu \mathrm{mol} \mathrm{DIC} \mathrm{h}{ }^{-1}\right)$ was calculated as the variation in the 176 dissolved inorganic carbon $(D I C)$ concentration between the start and the end of the

177 incubation using the following equation: $R=(\Delta D I C \times v) /\left(\Delta t \times 10^{3}\right)-G$, where $\Delta D I C$ is

178 the variation in DIC during incubation ( $\mu$ mol DIC ${ }^{-1}$ ), $\Delta t$ is the incubation time $(\mathrm{h}), v$ is the

179 bottle volume (l) and $G$ is the calcification rate $\left(\mu \mathrm{mol} \mathrm{CaCO}_{3} \mathrm{~h}^{-1}\right)$. To determine the dissolved 
180 inorganic carbon (DIC) concentration $\left(\mu \mathrm{mol} \mathrm{L}^{-1}\right)$, seawater samples were taken from

181 incubation bottles at the start and at the end of each incubation in order to measure total 182 alkalinity (TA), $\mathrm{pH}$ and seawater temperature.

183 TA samples were obtained by filtering water through $0.7 \mu \mathrm{m}$ Whatman $\mathrm{GF} / \mathrm{F}$ filters.

184 Samples were then stored with $250 \mathrm{ml}$ plastic bottles in the dark. Laboratory analysis consisted

185 in estimating TA ( $\mu \mathrm{mol} \mathrm{L}{ }^{-1}$ ) within $20 \mathrm{ml}$ subsamples (average of 6 subsamples per bottle) by 186 automatic potentiometric titration (Radiometer, Titrilab TIM 865). Subsamples were titrated 187 by adding small increments of $0.01 \mathrm{~mol} \mathrm{~L}^{-1} \mathrm{HCL}$ with $0.7 \mathrm{~mol} \mathrm{~kg}^{-1} \mathrm{NaCl}$ to approximate the 188 ionic strength of sea water (Dickson \& Goyet, 1994) until about pH 3. TA was determined 189 using the modified Gran method by determining the second endpoint of the titration curve.

190 The $\mathrm{pH}$ (total scale) was measured using a $\mathrm{pH}$ probe (Radiometer $\mathrm{pHC} 2401$ ) which was 191 standardized with buffer solutions in synthetic seawater of 35\%o (Tris-HCL: 2-amino-2 192 hydroxymethyl-1,3-propanediol hydrochloride; 2-amminopyridine/HCL). pH values were 193 measured immediately after opening bottles in order to prevent effects of $\mathrm{CO}_{2}$ exchange with 194 the air.

195 DIC concentration was calculated from $\mathrm{pH}$, TA, temperature, salinity, phosphate and silicate 196 concentrations using the CO2SYS program (Pierrot et al., 2006). The natural salinity, 197 phosphate and silicate concentrations were obtained using data collected in the Bay of Brest 198 by the French coastal observation service (SOMLIT: Service d'Observation en Milieu 199 Littoral, INSU-CNRS, St Anne du Portzic). Dissociation constants for carbonic acid K1 and 200 K2 were taken from Roy et al. (1993).

CALCIFICATION RATE

203 Calcification was determined using the alkalinity anomaly technique (Smith \& Key, 1975) in 204 each incubated bottle. Calcification rate $\left(G\right.$ in $\mu$ mol $\left.\mathrm{CaCO}_{3} \mathrm{~h}^{-1}\right)$ was calculated as follows: 
$205 G=(\Delta T A \times v) /(2 \times \Delta t) . \Delta T A, \Delta t$ and $v$ corresponds to the variation in TA during 206 incubation $\left(\mu \mathrm{mol} \mathrm{l}^{-1}\right)$, incubation time (h) and bottle volume $(\mathrm{L})$, respectively. This equation is 207 based on the evidence that the precipitation of one mole of $\mathrm{CaCO}_{3}$ implies the consumption of 2082 moles of $\mathrm{HCO}_{3}^{-}$which decreases TA by 2 equivalents (Frankignoulle et al., 1994). $\mathrm{G}>0$ is 209 indicative of calcification, whilst $G<0$ indicates carbonate dissolution.

\section{AMMONIUM EXCRETION RATE}

212 Ammonia is assumed to be the primary end product of catabolism of amino acids in molluscs 213 (Bayne and Newell, 1983). Besides providing us information regarding H. tuberculata 214 ammonium excretion, $\mathrm{NH}_{4}{ }^{+}$concentrations were measured to correct $\mathrm{TA}$ since ammonium 215 excretion is one of the processes that may affect TA in our experiments (Gazeau et al., 2014, 216 2015). Ammonium excretion was obtained by collecting seawater samples at the beginning 217 and end of each incubation in $10 \mathrm{ml}$ vials and kept at $-20^{\circ} \mathrm{C}$ until analysis. The phenol218 hypochlorite method (Koroleff, 1969; Sororzano, 1969) was used to determine $\mathrm{NH}_{4}^{+}$

219 concentration $\left(\mu \mathrm{mol} \mathrm{L}{ }^{-1}\right)$. After adding reagents, the coloration of each sample was measured 220 at $630 \mathrm{~nm}$ using a spectrophotometer. Nitrification process was not assessed here since it can 221 be considered to be negligible under short incubations (Tagliarolo et al., 2013b; Lorrain et al., 222 2015).

\section{AERIAL RESPIRATION MEASUREMENTS}

225 Each abalone were detached and placed into a 0.1-L airtight dark chamber connected to a 226 closed circulation system with an integrated infrared $\mathrm{CO}_{2}$ analyser (Li-Cor, Li-820) and a 227 desiccation column filled with anhydrous calcium sulphate (Drierite, Xenia, USA) just after 228 emersion. An adjustable pump maintained air flow at 0.8-0.9 $\mathrm{L} \mathrm{min}^{-1}$. Aerial respiration 229 within each chamber was estimated by the linear slope of $\mathrm{CO}_{2}$ concentration increase 
230 measured every 5 seconds over 3 minutes using the Li-820 software (Clavier et al., 2009).

231 Fluxes of $\mathrm{CO}_{2}\left(\mu \mathrm{mol} \mathrm{CO} \mathrm{CH}^{-1}\right)$ were corrected for the net volume of the system and incubation 232 time. The aerial temperature was maintained at that of the seawater during aquatic 233 incubations.

\section{Data analysis}

\section{SHELL COMMUNITY CONTRIBUTION AND INDIVIDUAL BIOMASS}

237 Calcification, aquatic and aerial respiration measurements were repeated on empty shells of 238 the same individuals. Shells were washed, cleared of any flesh and carefully dabbed inside 239 with a paper towel damped with $70 \%$ ethanol. The measured parameters for the shell 240 community were then subtracted to the total calcification and respiration rates. The parameter 241 values presented in this study are the shell community corrected values. The contribution of 242 the dissolution of the inner shell part was considered as negligible (maximum empty shell 243 calcification rate of $0.17 \mu \mathrm{mol} \mathrm{CaCO} 3 \cdot \mathrm{h}^{-1} \cdot \mathrm{g}^{-1}$ in September, and a minimal flux of $-0.03 \mu \mathrm{mol}$ $244 \mathrm{CaCO}_{3} \cdot \mathrm{h}^{-1} \cdot \mathrm{g}^{-1}$ in January).

245 All the studied parameters were further normalized to biomass as described below. 246 Individual biomass was estimated as ash-free dry weight (AFDW) through loss on ignition (4 $247 \mathrm{~h}$ combustion at $450^{\circ} \mathrm{C}$ of $60^{\circ} \mathrm{C}$ dried individuals until constant weight) and expressed in $\mathrm{g}$ $248 \mathrm{AFDW}^{-1}$.

\section{STATISTICAL ANALYSIS}

251 The relationship between the biomass (AFDW) and the physiological aquatic parameters were 252 assessed using the following allometric equation $Y=a \times W^{b}$ (Marsden et al., 2012) where a 253 corresponds to the physiological rate per gramme AFDW, and $b$ shows the rate at which the 254 physiological parameter evolves with the biomass. 
Normality and homogeneity of variances of the data distributions of calcification, aquatic

256

257

258

259

260

261

262

263

264

265

266

267

268

269

270

271

272

273

274

275

276

277

278

and aerial respiration, and ammonium excretion were investigated using the Shapiro-Wilk and Bartlett tests, respectively. An ANOVA was performed to study the seasonal variability. When normal distribution of the data distributions were not verified, the Kruskal Wallis test was used. When the assumption of homogeneity of variance was not verified, a Welch's ANOVA test was performed as recommended by Day and Quinn (1989). Subsequent non parametric post hoc analyses were conducted with the Tukey and Kramer (Nemenyi) test (Pohlert, 2014) to distinguish differences between seasons. The Wilcoxon Signed-Ranks test was run to compare aquatic and aerial respiration at each season.

The relationships between the aquatic respiration, calcification and excretion rates, and the seawater temperature experienced at each season were investigated using the Arrhenius equation after logarithmic transformation as a function of $T^{-1}$ as follows:

$$
\ln F \operatorname{lux}=\ln a-\frac{E_{A}}{K} \times \frac{1}{T}
$$

where Flux is respiration ( $\triangle \mathrm{DIC}$ aquatic or $\Delta \mathrm{CO}_{2}$ in the air, $\mu \mathrm{mol} \mathrm{g}^{-1} \mathrm{~h}^{-1}$ ), $a$ is a normalization constant, $E$ a is the activation energy $\left(\mathrm{J}_{\text {mole }}^{-1}\right), K$ is Boltzmann's constant $\left(8.31 \mathrm{~J} \mathrm{~K}^{-1} \mathrm{~mol}^{-1}\right)$, and $T$ is the absolute temperature $\left({ }^{\circ} \mathrm{K}\right)$.

Comparison of calcification, aquatic respiration and ammonium excretion between dayand night-time were conducted with the Wilcoxon Signed-Rank test.

As the data were normally distributed $(\mathrm{p}>0.05)$, hourly variations in aerial respiration over 6 hours emersion at different ambient temperatures $\left(10^{\circ} \mathrm{C}, 14^{\circ} \mathrm{C}\right.$ and $\left.18^{\circ} \mathrm{C}\right)$ were assessed using repeated measures ANOVA with a Greenhouse-Geisser Correction when the data violated the assumption of sphericity (Mauchly's test of sphericity). Post hoc tests incorporating the Bonferroni correction were done to distinguish differences in aerial respiration at different times of emersion. Also, ANOVA tests were conducted to compare abalone respiration rates between different temperatures $\left(10^{\circ} \mathrm{C}, 14^{\circ} \mathrm{C}\right.$ and $\left.18^{\circ} \mathrm{C}\right)$ at each hour 
279 of emersion. When significant, a subsequent posthoc test (Tukey's HSD test) was run to 280 distinguish which group(s) significantly differed.

281

282

283

284

285

286

287

288

289

290

291

292

293

294

295

296

297

298

299

300

301

302

303

\section{RESULTS}

\section{Seasonal variations}

A seasonal effect was observed on aquatic respiration (Welch test, $\mathrm{F}_{3,32}=19.25, \mathrm{P}<0.001$ ) and aerial respiration (Anova test, $\mathrm{F}_{3,60}=3.63, \mathrm{P}<0.05$ ). Aquatic respiration was significantly lower in autumn $\left(8.41 \pm 1.34 \mu \mathrm{mol}\right.$ DIC $\left.\mathrm{g} \mathrm{AFDW}^{-1} \mathrm{~h}^{-1}\right)$ and winter $(6.34 \pm 1.93 \mu \mathrm{mol}$ DIC g AFDW $\left.^{-1} \mathrm{~h}^{-1}\right)$ than in summer $\left(13.17 \pm 3.66 \mu \mathrm{mol}\right.$ DIC $\mathrm{g} \mathrm{AFDW}^{-1} \mathrm{~h}^{-1}$, Figure 2). Aerial respiration was significantly lower in winter $\left(1.49 \pm 0.66 \mu \mathrm{mol} \mathrm{CO}_{2} \mathrm{~g} \mathrm{AFDW}^{-1} \mathrm{~h}^{-1}\right)$ than in summer $\left(2.21 \pm 0.83 \mu \mathrm{mol} \mathrm{CO} \mathrm{g} \mathrm{AFDW}^{-1} \mathrm{~h}^{-1}\right.$, Figure 2).

Aerial respiration was significantly lower than aquatic respiration over the 4 seasons with abalone respiring between 5 and 6 times more underwater than during emersion (Table 1; Figure 2).

Calcification rates of abalone (net $\mathrm{CaCO} 3$ fluxes) had a mean annual value of $0.55 \pm 0.53$ $\mu \mathrm{mol} \mathrm{CaCO}_{3} \mathrm{~g} \mathrm{AFDW}^{-1} \mathrm{~h}^{-1}$. A seasonal effect was observed (Welch test, $\mathrm{F}_{3,27.5}=26.78, \mathrm{P}<$ 0.001) with $\mathrm{CaCO}_{3}$ fluxes significantly lower in winter (Figure 2) but with still $53 \%$ of individuals exhibiting shell calcification $(G>0) . \mathrm{CaCO}_{3}$ fluxes were positive in $88 \%$ of individuals in spring, and $100 \%$ of individuals in summer and autumn.

Ammonium fluxes were on average $0.29 \pm 0.26 \mu \mathrm{mol} \mathrm{NH^{4+ }} \mathrm{AFDW}^{-1} \mathrm{~h}^{-1}$ over the year. A seasonal effect was found (Welch test, $\mathrm{F}_{3,27.4}=5.88, \mathrm{P}<0.01$ ) with lower values measured in spring $\left(0.17 \pm 0.20 \mu \mathrm{mol} \mathrm{NH}{ }^{4+} \mathrm{AFDW}^{-1} \mathrm{~h}^{-1}\right)$ and winter $\left(0.19 \pm 0.07 \mu \mathrm{mol} \mathrm{NH}{ }^{4+} \mathrm{AFDW}^{-1} \mathrm{~h}^{-1}\right)$ than in summer $\left(0.36 \pm 0.22 \mu \mathrm{mol} \mathrm{NH}{ }^{4+} \mathrm{AFDW}^{-1} \mathrm{~h}^{-1}\right)$ and/or autumn $\left(0.47 \pm 0.36 \mu \mathrm{mol} \mathrm{NH} \mathrm{NH}^{4+}\right.$ $\mathrm{AFDW}^{-1} \mathrm{~h}^{-1}$, Figure 2). 
305 A good relationship was observed between aquatic respiration and calcification, and 306 temperature (respectively, $\mathrm{R}^{2}=0.88$ and $\mathrm{R}^{2}=0.70$, table 2 ). The relationship between aerial 307 respiration and temperature was rather high but lower than that of aquatic respiration $\left(\mathrm{R}^{2}=\right.$ 308 0.68, table 2). A poor relationship was observed between ammonium excretion and 309 temperature $\left(\mathrm{R}^{2}=0.35\right.$, table 2$)$.

\section{Day-night variations (in autumn only)}

312 Day- and night-time aquatic respiration rates were $8.41 \pm 1.34$ and $9.10 \pm 3.74 \mu \mathrm{mol}$ DIC g

$313 \mathrm{AFDW}^{-1} \mathrm{~h}^{-1}$, respectively, and did not differ significantly (Wilcoxon signed rank test, $\mathrm{P}=$ 314 0.64).

$315 \mathrm{CaCO}_{3}$ fluxes were significantly higher (Wilcoxon signed rank test, $\mathrm{P}<0.01$ ) during the 316 night than during the day $\left(1.19 \pm 0.72\right.$, and $0.71 \pm 0.47 \mu \mathrm{mol} \mathrm{CaCO}_{3} \mathrm{~g} \mathrm{AFDW}^{-1} \mathrm{~h}^{-1}$, 317 respectively).

318 Likewise, $\mathrm{NH}_{4}{ }^{+}$fluxes were significantly greater (Wilcoxon signed rank test, $\mathrm{P}<0.05$ ) 319 during the night than during the day $\left(0.50 \pm 0.17\right.$, and $0.47 \pm 0.36 \mu \mathrm{mol} \mathrm{NH}_{4}^{+} \mathrm{AFDW}^{-1} \mathrm{~h}^{-1}$, 320 respectively).

Both aquatic respiration and calcification rates per unit biomass decreased as the individual 324 biomass increased (aquatic respiration: $y=28.066 \times x^{-0.484}, R^{2}=0.71$; calcification: $325 y=3.831 \times x^{-0.885}, R^{2}=0.76$; Figure 3). No distinguishable pattern was found between 326 the individual biomass and ammonium excretion rate $\left(R^{2}=0.004\right)$. 
329 At $10^{\circ} \mathrm{C}$, aerial respiration rates were lower at one hour of emersion than at 3,5 and 6 hours 330 of aerial exposure (Repeated measure Anova test, $\mathrm{F}_{5,35}=13.98, \mathrm{P}<0.001$, Figure 4 ). At $14^{\circ} \mathrm{C}$, 331 abalone significantly respired less after one hour of emersion than at 4 and 6 hours of 332 emersion (repeated measures Anova test, $F_{3.1,21.6}=5.43, P<0.01$, Figure 4). No difference in 333 respiration rate was observed over the 6 hour emersion at $18^{\circ} \mathrm{C}\left(\mathrm{F}_{2.1,6.7}=1.13\right.$, Figure 4$)$.

334 Significant differences in aerial respiration rates between temperatures were obtained at 1 335 hour (Anova test, $\mathrm{F}_{2,21}=5.46, \mathrm{P}<0.05$ ), 2 hours (Anova test, $\mathrm{F}_{2,21}=5.25, \mathrm{P}<0.05$ ), 4 hours 336 (Anova test, $\mathrm{F}_{2,20}=3.94, \mathrm{P}<0.05$ ) and 6 hours (Anova test, $\mathrm{F}_{2,20}=5.54, \mathrm{P}<0.05$ ) of emersion 337 : abalone significantly displayed lower respiration rates at $10^{\circ} \mathrm{C}$ than at $18^{\circ} \mathrm{C}$ after 1 hour of 338 emersion (Test HSD de Tukey, $\mathrm{P}<0.01$, Figure 4). At 2 and 4 hours of emersion, abalone 339 displayed lower rates at $10^{\circ}$ than $14^{\circ} \mathrm{C}$ (Test HSD de Tukey, $\mathrm{P}<0.05$, Figure 4). At 6 hours 340 of emersion, abalone displayed lower rates at $18^{\circ}$ than $14^{\circ} \mathrm{C}$ (Test HSD de Tukey, $\mathrm{P}<0.05$, 341 Figure 4).

\section{DISCUSSION}

\section{Effect of Haliotis tuberculata biomass upon its physiological rate}

345 Body size has been identified as a good proxy for metabolic rates of animals (Newell, 1973).

346 Abalone respiration rates increase as weight increases (Gaty \& Wilson, 1986; Basuyaux et al., 347 2001; Cunningham et al., 2016). An allometric relationship between aquatic respiration and 348 calcification rates per unit biomass was observed with negative $b$ values much less than unity 349 which indicates that respiration and calcification do not decrease in direct proportion to 350 biomass (Marsden et al., 2012). Our results i.e. higher aquatic respiration and calcification 351 rates per unit biomass in smaller $H$. tuberculata individuals, corroborate the evidence that 352 metabolic demand and growth decrease with age (at least during the first years of growth) like 353 in others molluscs such as Tectus niloticus (Lorrain et al., 2015), Crepidula fornicata (Martin 
354 et al., 2006), Mytilus edulis and M. galloprovincialis (Tagliarolo et al., 2012). Previous

355 findings in $H$. tuberculata have also found that growth rate, underpinned by metabolism and 356 energy budgets, decreases progressively as its size increases (Hayashi, 1980b; Clavier \& 357 Richard, 1986; Roussel et al., 2011). However, because one part of the small abalone were 358 from a farmed origin, resulting from systematic mating between wild and farmed broodstock, 359 it cannot be excluded that acclimation to the farm may have slightly modified physiological 360 rates compared to the wild abalone. In addition, because respiration was tested in still water 361 conditions, both respiration and calcification values may be greater in animals in moving 362 water on farm or in the wild (Taylor and Ragg, 2005).

363

364

365

366

No relationship was observed between $H$. tuberculata ammonium excretion rate and biomass as in the trochus T. niloticus (Lorrain et al., 2015). This may indicate a similar excretion rate per unit biomass for adults and juveniles. The rate of excretion per unit of biomass diminishes in mussels as individuals grow larger (Vaughn \& Hakenkamp, 2001; Tagliarolo et al., 2012). A positive correlation however has been reported between body size and ammonium excretion rates per individual in Haliotis discus discus, $H$. gigantea and $H$. madaka (Ahmed et al., 2008).

\section{Seasonal variations in Haliotis tuberculata physiological parameters}

$H$. tuberculata aquatic respiration showed a 2-fold seasonal difference with minimal rates in winter and maximal rates in summer. Seasonal variations in aquatic respiration have been observed in many others benthic molluscs. From 1.6 up to five-fold differences in aquatic respiration rates between winter and summer have been observed in Patella vulgata (Tagliarolo et al., 2013b), C. fornicata community (Martin et al., 2007), Crassostrea gigas 
378 (Lejart et al., 2012), the trochus T. niloticus (Lorrain et al 2015) and the abalone $H$. 379 tuberculata (Gaty \& Wilson, 1986).

380 In our experiment, aerial respiration was minimal in winter $\left(1.49 \pm 0.66 \mu \mathrm{mol} \mathrm{CO}_{2} \mathrm{~g}\right.$ $\left.381 \mathrm{AFDW}^{-1} \mathrm{~h}^{-1}\right)$ and maximal in summer $\left(2.21 \pm 0.83 \mu \mathrm{mol} \mathrm{CO}_{2} \mathrm{~g} \mathrm{AFDW}^{-1} \mathrm{~h}^{-1}\right)$ with an average 382 5-fold higher for aquatic respiration compared to aerial respiration. Seasonal aerial respiration 383 has not been extensively studied in molluscs. However, this experiment showed that season 384 has similar effects on underwater and aerial respiration. This can have direct consequences on 385 live transport procedure. As respiration rates and energy demand are higher in summer, it 386 might be more appropriate to transport live abalone during winter when energy needs are 387 lower and when the recovery time post-air exposure may be less.

$388 \mathrm{CaCO}_{3}$ accretion showed that $53 \%$ of $\mathrm{H}$. tuberculata individuals did not stop their growth 389 over winter in Britanny temperature conditions. The seasonal growth pattern reported in this 390 study is consistent with previous observations in $H$. tuberculata : abalone growth rate was 391 found to drop in winter whilst $70 \%$ of annual growth occurred between May and November 392 (Clavier \& Richard, 1986). Similarly, more recent studies using stable oxygen isotopes 393 techniques have found that $H$. tuberculata does not stop its growth in winter (Roussel et al., 394 2011; Jolivet et al., 2015). $\mathrm{CaCO}_{3}$ accretion in $H$. tuberculata was greater in warmer months 395 when the temperature and the development of the gonad maturation are near its maximum 396 (Hayashi, 1980a) and decreased over winter leading to a net calcification rate over the year $397\left(0.55 \pm 0.53 \mu \mathrm{mol} \mathrm{CaCO}_{3} \mathrm{~g} \mathrm{AFDW}^{-1} \mathrm{~h}^{-1}\right)$. In contrast, the abalone Haliotis discus hannai 398 showed retardation in growth during gonad maturation and spawning (Sakai, 1960). Seasonal 399 variation in $\mathrm{CaCO}_{3}$ accretion is common in molluscs; higher $\mathrm{CaCO}_{3}$ fluxes have been found in 400 warmer months (Martin et al., 2006; Lejart et al., 2012) whilst $\mathrm{CaCO}_{3}$ accretion decreases or 401 stops in winter (Lejart et al., 2012; Tagliarolo et al., 2013b). 
Finally, ammonium excretion rates in H. tuberculata also varied seasonally; lower average

403

404

405

406

407

408

409

410

411

values were measured in spring and winter $\left(0.17-0.19 \mu \mathrm{mol} \mathrm{NH}{ }_{4}^{+} \mathrm{AFDW}^{-1} \mathrm{~h}^{-1}\right.$, respectively) whilst maximal average values were found in summer and autumn $\left(0.37-0.47 \mu \mathrm{mol} \mathrm{NH}_{4}^{+}\right.$ $\mathrm{AFDW}^{-1} \mathrm{~h}^{-1}$, respectively). These results are consistent with the variations in excretion rates reported for the limpet $P$. vulgata; low shore individuals had fluxes ranging from 0.5 to 0.7 $\mu \mathrm{mol} \mathrm{NH}_{4}^{+} \mathrm{AFDW}^{-1} \mathrm{~h}^{-1}$ in winter and in summer, respectively (Tagliarolo et al., 2013b). In contrast, other mollusc species showed maximum excretion rates in spring (Martin et al., 2006) and minimum rates in winter (Bayne \& Scullard, 1977; Martin et al., 2006).

This seasonal pattern in $H$. tuberculata physiological rates can be explained by both environmental stressors (e.g. temperature), and biogenic factors (e.g. reproductive needs, resource abundance, distribution and availability).

Seasonal variation in temperature was most likely the primary driver of the observed seasonal variations in carbon fluxes in this study. This hypothesis is consistent with the strong relationships observed between temperature and the studied physiological rates (except ammonium rates); lower rates occurred in winter when the temperature was $11^{\circ} \mathrm{C}$ and maximal rates were recorded in summer when the temperature reached $18.3^{\circ} \mathrm{C}$. Temperature is known to impact all physiological rates in ectotherms (Somero, 2002) and it has been showed to influence the aquatic respiration of many mollusc species (Lejart et al., 2012; Tagliarolo et al., 2013a, 2013b). As temperature increases, the oxygen demand increases as more energy is required to fulfill physiological requirements. This has already been reported in $H$. tuberculata, which exhibited lower oxygen consumption rates at $8^{\circ} \mathrm{C}$ compared to $16^{\circ} \mathrm{C}$ or $18^{\circ} \mathrm{C}$ (Gaty \& Wilson, 1986).

Biotic factors such as food abundance can contribute to respiration rates. Abalone are herbivorous (Stephenson, 1924) and mostly sedentary (Clavier \& Richard, 1982). Abalone increase their feeding activity in summer (Allen et al., 2006) when their resources i.e. drifting 
427 seaweed (Clavier \& Chardy, 1989) are more abundant following summer macroalgal blooms 428 on the Atlantic coast (Dion \& Le Bozec, 1996). Fresh algae were provided ad libitum before 429 the experiment in order to reduce variability due to starvation since at the same temperature, 430 oxygen consumption rate is $30 \%$ lower in 2-weeks starved abalone compared to fed $H$. 431 tuberculata (Gaty \& Wilson, 1986). Because H. tuberculata are more inclined to forage in 432 summer (Roussel, pers. comm.), higher aquatic and aerial respiration rates in summer may be 433 related to higher metabolic demands as more energy is required for digestion, absorption and 434 assimilation processes (Widdows \& Shick, 1985). Higher respiration rates may also be related 435 to the production of large gonad. Indeed, the spawning period has been associated with 436 increased metabolic demand as energy is required to produce gametes (Hayashi, 1983). 437 Finally, the low growth and the decrease in excretion rates may be associated with less 438 abundant resources over winter (Allen et al., 2006).

\section{Day-night variations in $H$. tuberculata physiological parameters}

441 H. tuberculata is characterised like other abalone species (Momma \& Sato, 1970; Barkai \& 442 Griffiths, 1987) by nocturnal behaviour with movements that are initiated an hour after sunset 443 (Werner et al., 1995). However, unlike other gastropods such as the abalone $H$. discus hannai 444 (Uki \& Kikuchi, 1975), and the trochus T. niloticus (Lorrain et al., 2015) which display 445 higher metabolic rates whilst being active overnight, no circadian rhythm in $H$. tuberculata 446 aquatic respiration was observed. Movement of the animal could not be controlled in most of 447 the experiment design. The apparatus used in this experiment allowed movement of the 448 abalone inside the bottle, and no movement restraint was used. However, no abalone 449 movements were observed during visual observation of the bottle, even if punctual movement 450 cannot be completely excluded. This result probably indicates that aquatic respiration is 
451 similar during night and day periods. However, we cannot exclude that aquatic respiration

452 would be in average higher at night when abalone is crawling to get food.

453 Intrinsic higher metabolic rates overnight may also explain the counterintuitive greater 454 ammonium fluxes at night than during the day, even though the difference was small $(0.03$ $455 \mu \mathrm{mol} \mathrm{NH}{ }_{4}^{+} \mathrm{AFDW}^{-1} \mathrm{~h}^{-1}$ ). Indeed since $H$. tuberculata has a nocturnal feeding habit like the 456 abalone $H$. midae, ammonium excretion was expected to be higher during the diurnal 457 elimination phase (Barkai \& Griffiths, 1987). Further research is required to determine the 458 factors driving day-night patterns of ammonium fluxes in H. tuberculata.

459 H. tuberculata calcifies 1.7 fold more at night than during the day. Diurnal growth ridge 460 formation in other gastropods like the limpet Acmaea antillarum have been related to the 461 light-dark cycle (Kenny, 1977). Since incubations at both day- and night-times were 462 conducted in dark conditions, the calcification process in H. tuberculata may be intrinsic and 463 be related to its nocturnal behaviour and related higher metabolic activity in the same way as 464 the trochus T. niloticus (Lorrain et al., 2015). More research is required to examine the 465 day/night pattern in calcification rates in shelled gastropods, which has to date been poorly 466 documented.

\section{H. tuberculata aerial respiration during 6-h exposure}

H. tuberculata aerial carbon respiration represents ca. $20 \%$ of aquatic carbon respiration, which is in the range of what has been observed in intertidal mussels (19\%-23\%, Tagliarolo et al., 2012) but lower than others intertidal gastropod species (40\%-230\%) (Tagliarolo et al.,

472 2013a). The low emersion/immersion ratio i.e. 0.2 , may be an energy saving strategy for emerged $H$. tuberculata individuals which potentially implies a switch to anaerobic processes

474 (Widdows \& Shick, 1985). Another explanation of this lower aerial respiration would be the 475 collapse of the gill in the air, so that the respiration would be limited. This indicates that $H$. 
476 tuberculata can physiologically adapt to emersion like others intertidal gastropods. However, 477 regardless carefully handling of abalone, it cannot be excluded that acute stress response due 478 to detachment modified, at least partly, aerial respiration at the beginning of the measurement 479 period. Further research is however required to better understand aerobic and anaerobic 480 pathways during emersion in H. tuberculata.

481 Some intertidal gastropods have been shown to either decrease aerial respiration over 482 emersion or to maintain stable rates (Tagliarolo et al., 2013a, 2013b). Here, abalone increased 483 their aerial respiration over time at $10^{\circ} \mathrm{C}$ and $14^{\circ} \mathrm{C}$. At $18^{\circ} \mathrm{C}$, aerial respiration was already 484 high in the first hour of aerial exposition and no further increase was observed over time. 485 Similarly, mussels (M. edulis) showed an increase in aerial energy expenditure when exposed 486 to the air for longer than under natural conditions (Widdows \& Shick, 1985). Abalone are 487 mostly found in subtidal areas or at the low shore level of intertidal rocky shores, therefore 488 intertidal abalone are emerged for short periods of time in nature i.e. less than 3 hours, rather 489 than the imposed 6 hours of emersion of this study. Respiration rates in H. tuberculata started 490 to increase after 3 hours of emersion at the anticipated time of re-immersion. This result 491 showed that $H$. tuberculata can handle emersion during 3 hours with probably very limited energetic cost. However, after 3 hours of emersion, abalone increased their respiration rate (at $10^{\circ} \mathrm{C}$ and $14^{\circ} \mathrm{C}$ ) which suggests higher metabolic cost of longer emersion period at these 494 temperatures (up to 6 hours in this study) and potential physiological impacts on the recovery 495 time (and higher post-emersion mortality). Respiration rates at $10^{\circ} \mathrm{C}$ were lower than at 496 greater temperatures after 1, 2 and 4 hours of emersion. This suggests that transporting live 497 ormers at low temperature $\left(10^{\circ} \mathrm{C}\right)$ using ice packs for short time period may minimize the 498 metabolic cost of emersion and hence may improve survival rates during the post-emersion 499 recovery period (Buen-Ursua \& Ludevese, 2011). 
502 This study has underscored that (i) aquatic carbon respiration and calcification rates per unit

503 biomass are higher in smaller ormers, (ii) rates of physiological parameters are lower in 504 winter than in summer, in particular, ormers do not stop calcifying in winter, (iii) calcification 505 and excretion rates are higher at night than during the day, (iv) aerial carbon respiration 506 corresponds to $20 \%$ of aquatic respiration which indicates that $H$. tuberculata is adapted to 507 periods of emersion. The clear patterns of variations in $H$. tuberculata physiological rates 508 reported in the present study may constitute important information to understand the 509 relationship between growth, survival and metabolism during farming procedures.

510

\section{ACKOWLEDGMENTS}

512 We thank SOMLIT group for providing temperature and nutrient data, and for gas-analyser 513 calibration (http//somlit.epoc.u-bordeaux1.fr/fr/). We thank the anonymous reviewers for their 514 comments, suggestions and inputs which greatly improved an earlier version of this work.

515

\section{$516 \quad$ FINANCIAL SUPPORT}

517 This work was supported by the "Laboratoire d'Excellence" LabexMER (ANR-10-LABX-19)

518 and co-funded by a grant from the French government under the program "Investissements

519 d'Avenir", and by a grant from the Regional Council of Brittany (SAD programme). C

520 Chapperon was also supported by a grant from the Departmental council of Finistère. This 521 project received the support of the PIA-ANR IDEALG BTBR-10-04.

522

523

\section{REFERENCES}

524 Ahmed F., Segawa S., Yokota M. and Watanabe S. (2008) Effect of light on oxygen 525 consumption and ammonia excretion in Haliotis discus discus, H. gigantea, H. madaka and 
526 their hybrids. Aquaculture 279, 160-165.

527 Allen V.J., Marsden I.D., Ragg N.L.C. and Gieseg S. (2006) The effects of tactile stimulants 528 on feeding, growth, behaviour, and meat quality of cultured Blackfoot abalone, Haliotis iris.

529 Aquaculture 257: 294-308.

530 Baldwin J., Wells R.M.G., Low M. and Ryder J.M. (1992) Tauropine and D-lactate as

531 metabolic stress indicators during transport and storage of live paua, (New Zealand abalone)

532 (Haliotis iris). Journal of Food Science 57: 280-282.

533 Barkai R. and Griffiths C.L. (1987) Consumption, absorption efficiency, respiration and 534 excretion in the South African abalone Haliotis midae. South African Journal of Marine 535 Science 5: 523-529.

536 Basuyaux O., Mathieu M. and Richard O. (2001) Influence de Ia taille, de la température et du 537 régime alimentaire sur la consommation d'oxygène de l'oursin. Marine Life 11: 57-67.

538 Bayne B.L .and Scullard C. (1977) Rates of nitrogen excretion by species of Mytilus (Bivalvia: 539 Mollusca). Journal of the Marine Biological Association of the United Kingdom 57: 355-369.

540 Bayne B.L. and Newell R.C. (1983). Physiological energetics of marine molluscs. The $541 \quad$ Mollusca 4: 407-515.

542 Buen-Ursua S.M.A. and Ludevese G. (2011) Temperature and size range for the transport of 543 juvenile donkey's ear abalone Haliotis asinina Linne. Aquaculture Research 42: 1206-1213.

544 Carefoot T.H., Taylor B.E. and Donovan D.A. (1998) Seasonality in digestive-gland size and 545 metabolism in relation to reproduction in Haliotis Kamtschatkana. Journal of Shellfish $546 \quad$ Research 17: 713-716.

547 Chiou T.K., Lai M.M. and Shiau C.Y. (2001) Seasonal variations of chemical constituents in 548 the muscle and viscera of small abalone fed different diets. Fisheries Science 67: 146-156. 
549 Clavier J., Castets M.-D., Bastian T., Hily C., Boucher G.and Chauvaud L. (2009) An

550 amphibious mode of life in the intertidal zone: aerial and underwater contribution of

551 Chthamalus montagui to $\mathrm{CO}_{2}$ fluxes. Marine Ecology Progress Series 375: 185-194.

552 Clavier J. and Chardy P. (1989) Investigation into the ecology of the ormer (Haliotis

553 tuberculata L.), factors influencing spatial distribution. Aquatic living resources 2: 191-197.

554 Clavier J. and Richard O. (1982) Etude expérimentale du déplacement de l'ormeau (Haliotis

555 tuberculata) dans le milieu naturel. Revue des Travaux de l'Institut des Pêches Maritimes 46:

$556 \quad 315-326$.

557 Clavier J. and Richard O. (1986) Growth of juvenile Haliotis tuberculata (Mollusca:

558 Gastropoda) in their natural environment. Journal of the Marine Biological Association of the

559 United Kingdom 66: 497-503.

560 Cook P.A. (2014) The worldwide abalone industry. Modern Economy 5: 1181-1186.

561 Cooke S.J., Blumstein D.T., Buchholz R., Caro T., Fernández-Juricic E., Franklin C.E.,

562 Metcalfe J., O’Connor C.M., Clair C.C.S., Sutherland W.J. and Wikelski M. (2014)

563 Physiology, Behavior, and Conservation. Physiological and Biochemical Zoology 87: 1-14.

564 Crofts D.R. (1929) Haliotis (No. 29). The University Press of Liverpool.

565 Cunningham S.C., Smith A.M. and Lamare M.D. (2016) The effects of elevated $\mathrm{pCO}_{2}$ on

566 growth, shell production and metabolism of cultured juvenile abalone, Haliotis iris.

567 Aquaculture Research 47: 2375-2392.

568 Day R. W. and Quinn G. P. (1989) Comparisons of treatments after an analysis of variance in 569 ecology. Ecological Monographs 59: 433-463.

570 Dickson A.G. and Goyet C. (1994) Handbook of methods for the analysis of the various 571 parameters of the carbon dioxide system in sea water. Version 2. Oak Ridge National Lab., 

TN (United States).

573 Dion P. and Le Bozec S. (1996) The French atlantic coasts. In Marine Benthic Vegetation. 574 Springer Berlin Heidelberg. 251-264.

575 Forster G.R. (1967) The growth of Haliotis tuberculata: results of tagging experiments in 576 Guernsey 1963-65. Journal of the Marine Biological Association of the UK 47: 287-300.

577 Frankignoulle M., Canon C. and Gattuso J.P. (1994) Marine calcification as a source of 578 carbon dioxide: positive feedback of increasing atmospheric $\mathrm{CO}_{2}$. Limnology and 579 Oceanography 39: 458-462.

580 Gao X., Xian L., Meijie L., Changbin S. and Ying. L (2016) Effects of light intensity on 581 metabolism and antioxidant defense in Haliotis discus hannai Ino. Aquaculture 465: 78-87.

582 Gaty G. and Wilson J.H. (1986) Effect of body size, starvation, temperature and oxygen

583 tension on the oxygen consumption of hatchery-reared ormers Haliotis tuberculata L.

584 Aquaculture 56: 229-237

585 Gazeau F., Alliouane S., Bock C., Bramanti L., López Correa M., Gentile M., Hirse T., 586 Pörtner H.-O. and Ziveri P. (2014) Impact of ocean acidification and warming on the 587 Mediterranean mussel (Mytilus galloprovincialis). Frontiers in Marine Science 1: 1-12.

588 Gazeau F., Urbini L., Cox T.E., Alliouane S. and Gattuso J.P. (2015) Comparison of the 589 alkalinity and calcium anomaly techniques to estimate rates of net calcification. Marine 590 Ecology Progress Series 527: 1-12.

591 González R.C., Brokordt K. and Lohrmann K. B. (2012) Physiological performance of 592 juvenile Haliotis rufescens and Haliotis discus hannai abalone exposed to the withering 593 syndrome agent. Journal of Invertebrate Pathology 111: 20-26.

594 Hatae K., Nakai H., Shimada A., Murakami T., Takada K., Shirojo Y. and Watabe S. 
595 (1995) Abalone (Hariltis discus): Seasonal variations in chemical composition and textural 596 properties. Journal of Food Science 60: 32-35.

597 Hayashi I. (1980a) The reproductive biology of the ormer, Haliotis tuberculata. Journal of the 598 Marine Biological Association of the United Kingdom 60: 415-430.

599 Hayashi I. (1980b) Structure and growth of a shore population of the ormer, Haliotis 600 tuberculata. Journal of the Marine Biological Association of the United Kingdom 60: 431601437.

602 Hayashi I. (1983) Seasonal changes in condition factors and in the C: N ratio of the foot of the 603 ormer, Haliotis tuberculata. Journal of the Marine Biological Association of the United 604 Kingdom 63: 85-95.

605 Jolivet A., Chauvaud L., Huchette S., Legoff C., Thébault J., Nasreddine K., Schöne B.R. 606 and Clavier J. (2015) The ormer (Haliotis tuberculata): A new, promising paleoclimatic tool. 607 Palaeogeography, Palaeoclimatology, Palaeoecology 427: 32-40.

608 Kenny R. (1977) Growth studies of the tropical intertidal limpet Acmaea antillarum. Marine 609 Biology 39: 161-170.

610 Koroleff F. (1969) Direct determination of ammonia in natural waters as indophenol blue. 611 International Council for the Exploration of the Sea 9: 1-6.

\section{Lachambre S., Huchette S., Day R., Boudry P., Rio-Cabello A., Fustec T. and Roussel S.}

613 (2017) Relationships between growth, survival, physiology and behaviour - a multi-criteria 614 approach to Haliotis tuberculata phenotypic traits. Aquaculture 467: 190-197.

615 Lejart M., Clavier J., Chauvaud L. and Hily C. (2012) Respiration and Calcification of 616 Crassostrea gigas : contribution of an Intertidal Invasive Species to Coastal Ecosystem $\mathrm{CO}_{2}$ 617 Fluxes. Estuaries and Coasts 35: 622-632. 
618 Lorrain A., Clavier J., Thébault J., Tremblay-Boyer L., Houlbrèque F., Amice E., Le Goff

619 M. and Chauvaud L. (2015) Variability in diel and seasonal in situ metabolism of the

620 tropical gastropod Tectus niloticus. Aquatic Biology 23: 167-182.

621 Lu J., Shi Y., Cai S. and Feng J. (2017) Metabolic responses of Haliotis diversicolor to Vibrio 622 parahaemolyticus infection. Fish \& Shellfish Immunology 60: 265-274.

623 Marsden I.D., Shumway S.E. and Padilla D.K. (2012) Does size matter? The effects of body 624 size and declining oxygen tension on oxygen uptake in gastropods. Journal of the Marine 625 Biological Association of the United Kingdom 92: 1603-1617.

626 Martin S., Thouzeau G., Chauvaud L., Jean F., Guérin L.and Clavier J. (2006) Respiration, 627 calcification, and excretion of the invasive slipper limpet, Crepidula fornicata L.:

628 implications for carbon, carbonate, and nitrogen fluxes in affected areas. Limnology and 629 Oceanography 51: 1996-2007.

630 Martin S., Thouzeau G., Richard M., Chauvaud L., Jean F. and Clavier J. (2007) Benthic 631 community respiration in areas impacted by the invasive mollusk Crepidula fornicata. Marine 632 Ecology Progress Series 347: 51-60.

633 Mateos H.T., Lewandowski P.A. and Su X.Q. (2010) Seasonal variations of total lipid and 634 fatty acid contents in muscle, gonad and digestive glands of farmed Jade Tiger hybrid abalone 635 in Australia. Food Chemistry 123: 436-441.

636 Momma H. and Sato R. (1970) The locomotion behavior of the disc abalone, Haliotis discus 637 hannai Ino, in a tank. Tohoku journal of agricultural research 21: 20-25.

638 Morash A.J.and Alter K. (2015) Effects of environmental and farm stress on abalone 639 physiology: perspectives for abalone aquaculture in the face of global climate change. 640 Reviews in Aquaculture 8: 342-368.

641 Newell R.C. (1973) Factors affecting the respiration of intertidal invertebrates. Integrative and 
643 Pierrot D., Lewis E. and. Wallace D.W.R. (2006). MS Excel program developed for $\mathrm{CO}_{2}$ 644 system calculations. ORNL/CDIAC-105a. Carbon Dioxide Information Analysis Center, Oak 645 Ridge National Laboratory, US Department of Energy, Oak Ridge, Tennessee.

646 Pohlert T. (2014) The pairwise multiple comparison of mean ranks package (PMCMR). R 647 package.

648 Ragg, N.L.C. and Watts E. (2015) Physiological indicators of stress and morbidity in 649 commercially handled abalone Haliotis iris. Journal of Shellfish Research 34: 455-467.

650 Roussel S., Huchette S., Clavier J. and Chauvaud L. (2011) Growth of the European abalone 651 (Haliotis tuberculata L.) in situ: seasonality and ageing using stable oxygen isotopes. Journal 652 of sea research $65: 213-218$.

653 Roussel V., Charreyron J., Labarre S., Van Wormhoudt A. and Huchette S. (2013) First 654 steps on technological and genetic improvement of European abalone (Haliotis tuberculata) 655 based on investigations in full-sib families. Open Journal of Genetics 3: 224-233.

656 Roy R.N., Roy L.N., Vogel K.M., Porter-Moore C., Pearson T., Good C.E., Millero F.J. and 657 Campbell D.M. (1993) The dissociation constants of carbonic acid in seawater at salinities 5 658 to 45 and temperatures 0 to $45^{\circ} \mathrm{C}$. Marine Chemistry 44: 249-267.

659 Sakai S. (1960) On the formation of the annual ring on the shell of the abalone Haliotis discus 660 var Hannai ino. Tohoku journal of agricultural research 11: 239-244.

661 Shepherd S.A. (1973) Studies on southern Australian abalone (genus Haliotis). I. Ecology of 662 five sympatric species. Australian Journal of Marine and Freshwater Research 24: 217-258.

663 Smith S.V and Key G.S. (1975) Carbon dioxide and metabolism in marine environments.

664 Limnology and Oceanography 20: 493-495. 
665 Somero G.N. (2002) Thermal physiology and vertical zonation of intertidal animals: optima, 666 limits, and costs of living. Integrative and comparative biology 42: 780-789,

667 Sororzano L. (1969) Determination of ammonia in natural waters by the phenolhypochlorite 668 method. Limnology Oceanography 14: 799-801.

669 Stephenson T.A. (1924) Notes on Haliotis tuberculata. I. Journal of the Marine Biological 670 Association of the United Kingdom 13: 480-495.

671 Su X.Q., Antonas K., Li D.and Nichols P. (2006) Seasonal variations of total lipid and fatty 672 acid contents in the muscle of two Australian farmed abalone species. Journal of Food Lipids $673 \quad 13: 411-423$.

674 Tagliarolo M., Clavier J., Chauvaud L. and Grall J. (2013a) Carbon emission associated with 675 respiration and calcification of nine gastropod species from the intertidal rocky shore of 676 Western Europe. Marine Biology 160: 2891-2901.

677 Tagliarolo M., Clavier J., Chauvaud L., Koken M. and Grall J. (2012) Metabolism in blue 678 mussel: intertidal and subtidal beds compared. Aquatic Biology 17: 167-180.

679 Tagliarolo M., Grall J., Chauvaud L. and Clavier J. (2013b) Aerial and underwater 680 metabolism of Patella vulgata L.: comparison of three intertidal levels. Hydrobiologia 702: $681 \quad 241-253$.

682 Taylor, H. H. and Ragg, N. L. C. (2005) The role of body surfaces and ventilation in gas 683 exchange of the abalone, Haliotis iris. Journal of Comparative Physiology B-Biochemical 684 Systemic and Environmental Physiology, 175: 463-478.

685 Travers M.A., Le Goic N., Huchette S., Koken M. and Paillard C. (2008) Summer immune 686 depression associated with increased susceptibility of the European abalone, Haliotis 687 tuberculata to Vibrio harveyi infection. Fish \& Shellfish Immunology 25: 800-808. 
688 Uki N. and Kikuchi S. (1975) Oxygen consumption of the abalone, Haliotis discus hannai in 689 relation to body size and temperature. Bulletin of Tohoku Regional Fisheries Research 690 Laboratory 35: 73-84.

691 van Wormhoudt A., Gaume B., Le Bras Y., Roussel V. and Huchette S. (2011) Two different 692 and functional nuclear rDNA genes in the abalone Haliotis tuberculata: Tissue differential 693 expression. Genetica 139: 1217-1227.

694 Vaughn C.C. and Hakenkamp C.C. (2001) The functional role of burrowing bivalves in 695 freshwater ecosystems. Freshwater Biology 46: 1431-1446.

696 Venter L., Loots D.T., Vosloo A., van Rensburg P.J. and Lindeque J.Z. (in press) Abalone 697 growth and associated aspects: now from a metabolic perspective. Reviews in Aquaculture.

698 Wells R.M.G.and Baldwin J. (1995) A comparison of metabolic stress during air exposure in 699 two species of New Zealand abalone, Haliotis iris and Haliotis australis: Implications for the 700 handling and shipping of live animals. Aquaculture 134: 3-4.

701 Werner I., Flothmann S. and Burnell G. (1995) Behaviour studies on the mobility of two 702 species of abalone (Haliotis tuberculata and H. discus hannai) on sand: implications for 703 reseeding programmes. Marine and Freshwater Research 46: 681-688.

704 Widdows J. and Shick J.M. (1985) Physiological responses of Mytilus edulis and Cardium 705 edule to aerial exposure. Marine Biology 85: 217-232.

706 Young J.L., Bornik Z.B., Marcotte M.L., Charlie K.N., Wagner G.N., Hinch S.G. and 707 Cooke S.J. (2006) Integrating physiology and life history to improve fisheries management 708 and conservation. Fish and Fisheries 7: 262-283. 
TABLE CAPTIONS

711 Table 1. Comparison of aquatic (UW) and aerial (A) respiration in Haliotis tuberculata over

7124 seasons (Wilcoxon Signed Ranks Test).

713

714 Table 2. Relationships between metabolic parameters and temperature described by

715 Arrhenius equation $\ln F \operatorname{lux}=\ln a-\frac{E_{A}}{K} \times \frac{1}{T}$. Standards errors are in brackets.

716

717 FIGURE CAPTIONS

718 Fig. 1. Sea water temperature variations recorded at the SOMLIT station (St Anne du Portzic 719 site) over 12 months in 2014-2015. Grey squares indicate the field seawater temperature at 720 each sampling period (Sum: summer; Aut: autumn; Win: winter; Spr: spring).

722 Fig. 2. Haliotis tuberculata aquatic and aerial respiration, calcification and ammonium 723 excretion over 4 seasons in regards to seawater temperature (white dots: summer; dark grey 724 dots: autumn; black dots: winter; light grey dots: spring.) in 2014-2015. Values are means 725 and error bars are standard deviations. $\mathrm{n}=16$ in summer, $\mathrm{n}=15$ in autumn, $\mathrm{n}=17$ in winter and in spring. Significant differences $(\mathrm{p}<0.05)$ between seasons from Tukey and Kramer post hoc tests are indicated by letters.

Fig. 3. Allometric relation $\left(\mathrm{aAFDW} \mathrm{W}^{\mathrm{b}}\right.$ ) between individual abalone biomass (AFDW) and aquatic respiration (top graph), and calcification (bottom graph) in summer 2014 .

732 Fig. 4. Haliotis tuberculata aerial respiration during emersion at $10^{\circ} \mathrm{C}, 14^{\circ} \mathrm{C}$ and $18^{\circ} \mathrm{C}$.

733 Values are means and error bars are standard deviations $\left(\mathrm{n}=8\right.$ at $10^{\circ} \mathrm{C}$ and $14^{\circ} \mathrm{C} ; 6<\mathrm{n}<8$ at $\left.73418^{\circ} \mathrm{C}\right)$ 
3

4

\begin{tabular}{llll}
\hline Season & $\boldsymbol{Z}$ & $\boldsymbol{P}$ & Results \\
\hline Summer & -3.516 & $<0.001$ & $\mathrm{UW}>\mathrm{A}$ \\
Autumn & -3.408 & 0.001 & $\mathrm{UW}>\mathrm{A}$ \\
Winter & -3.574 & $<0.001$ & $\mathrm{UW}>\mathrm{A}$ \\
& & & \\
Spring & -3.516 & $<0.001$ & $\mathrm{UW}>\mathrm{A}$ \\
\hline
\end{tabular}


1

\begin{tabular}{lccc}
\hline Parameter & $\boldsymbol{l n} \boldsymbol{a}$ & $\boldsymbol{E} \boldsymbol{a} / \boldsymbol{K}$ & $\mathbf{R}^{2}$ \\
\hline Aquatic respiration & $30.23(7.46)$ & $8.06(2.15)$ & $0.88(0.13)$ \\
Calcification & $143.42(67.31)$ & $41.62(19.36)$ & $0.70(1.22)$ \\
Ammonium excretion & $27.47(27.96)$ & $8.28(8.04)$ & $0.35(0.50)$ \\
Aerial respiration & $15.65(7.27)$ & $4.34(2.10)$ & $0.68(0.13)$ \\
\hline
\end{tabular}

2 
Journal of the Marine Biological Association of the United Kingdom

Page 34 of 37

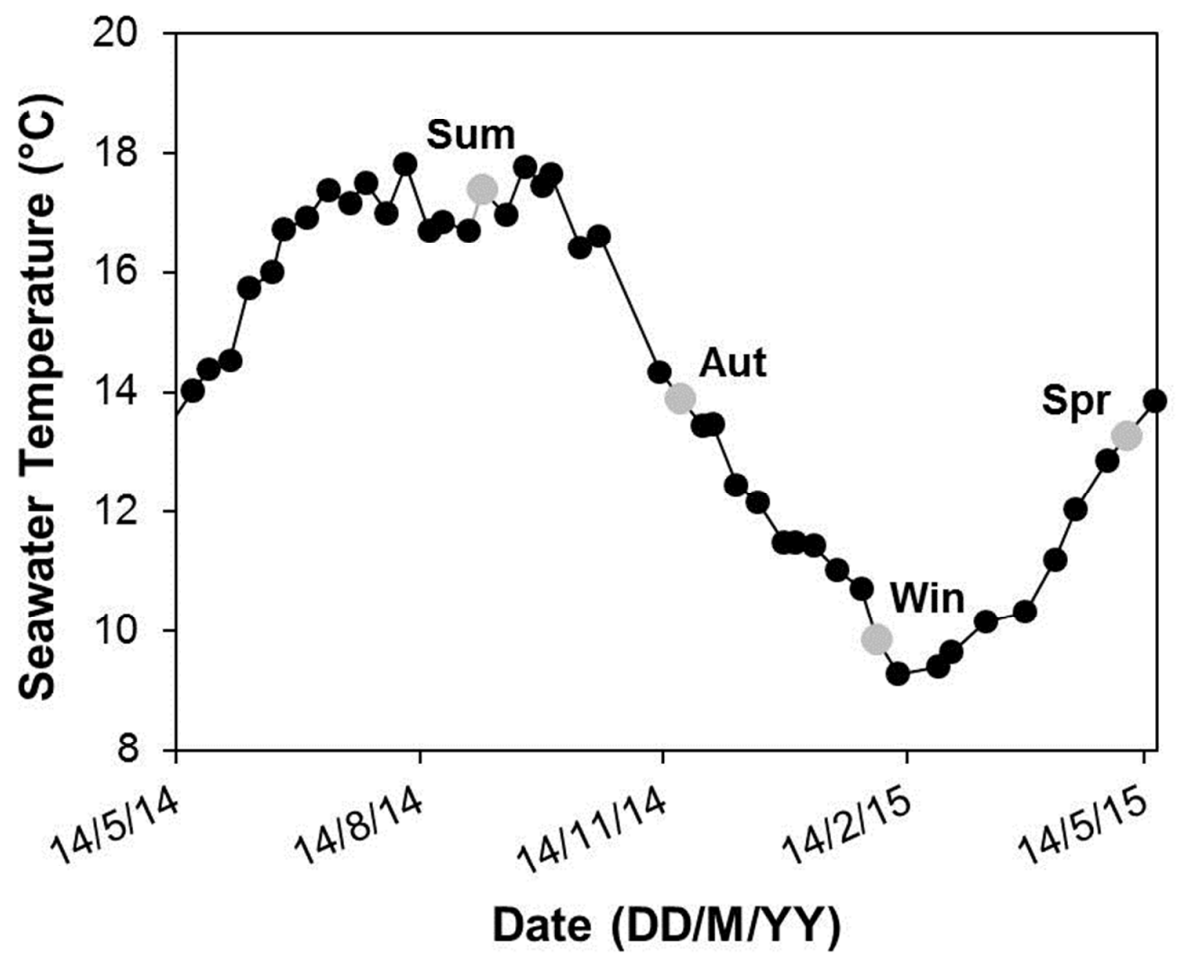

Cambridge University Press 

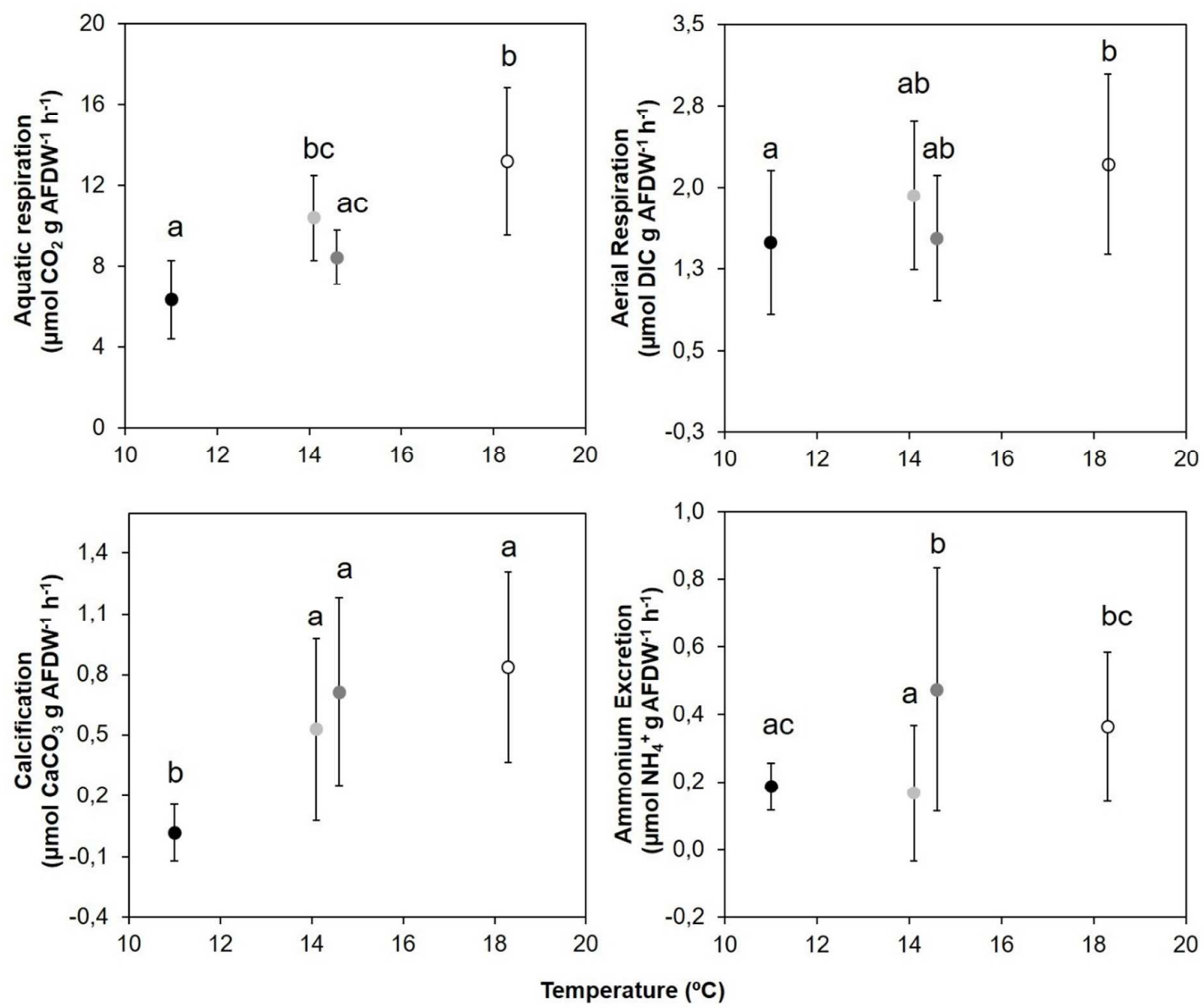

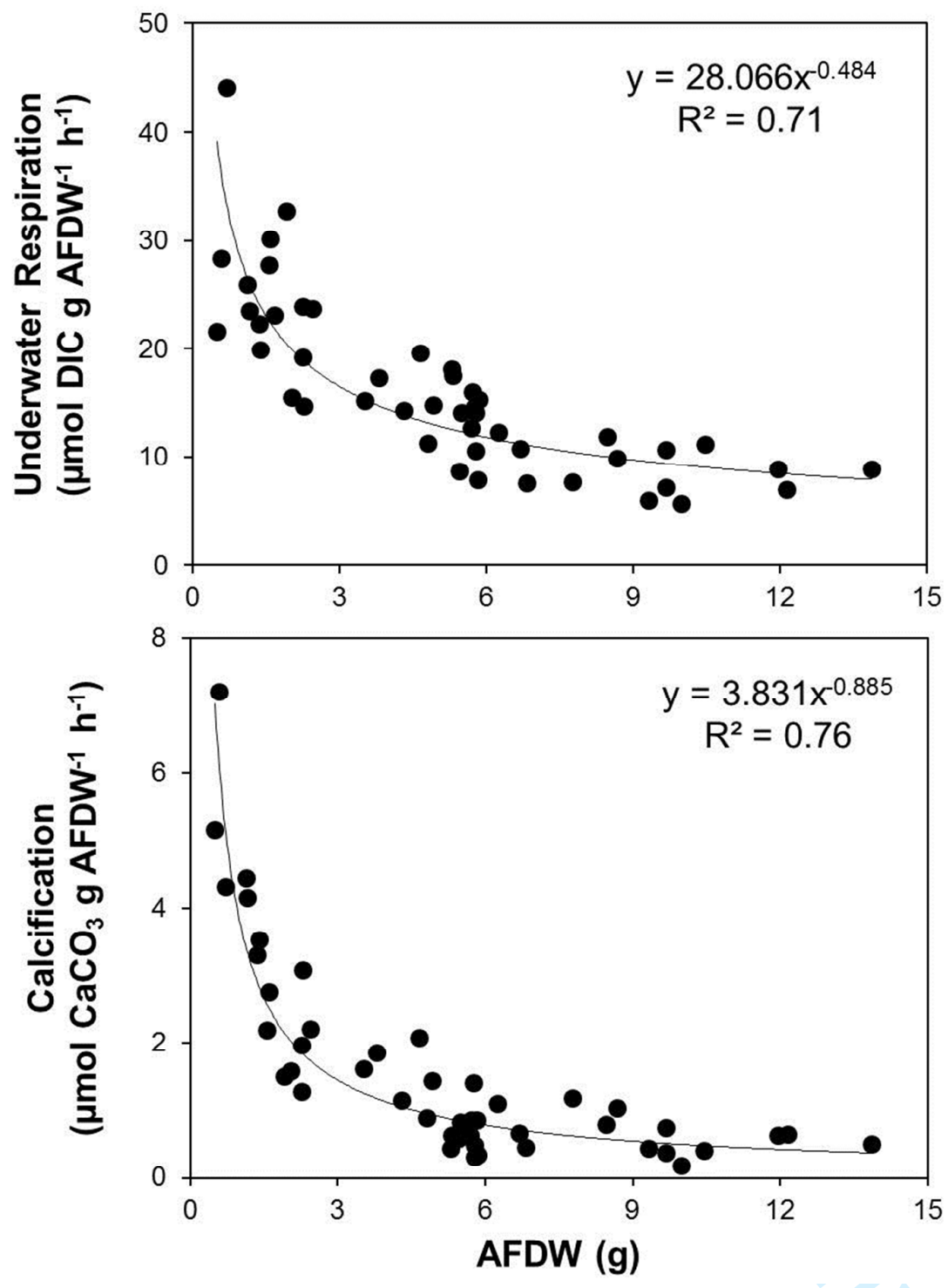

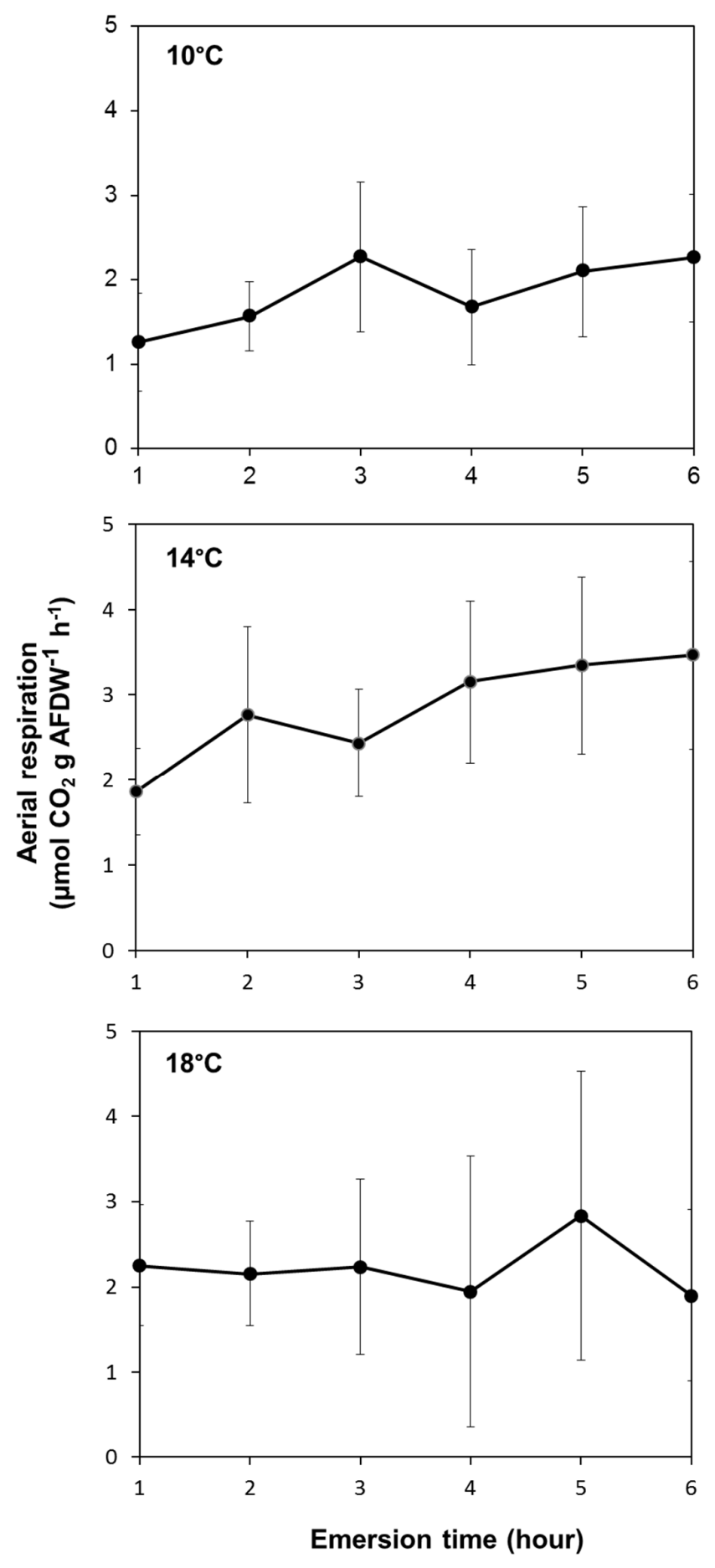